\title{
Grazing by the Antarctic fish Notothenia coriiceps: evidence for selective feeding on macroalgae
}

\author{
K. IKEN', E.R. BARRERA-ORO², M.L. QUARTINO², R.J. CASAUX ${ }^{2}$ and T. BREY' \\ ${ }^{I}$ Alfred Wegener Institute for Polar and Marine Research, Postfach 120 161, Columbusstraße, D-27568 Bremerhaven, Germany \\ ${ }^{2}$ Instituto Antártico Argentino, Cerrito 1248, (1010) Buenos Aires, Argentina
}

\begin{abstract}
In Potter Cove, King George Island, Antarctica, macroalgae provide a significant food resource for herbivores. The demersal fish Notothenia coriiceps feeds on macroalgae. Eighteen algal species were identified in stomach contents: two chlorophytes, ten rhodophytes and six phaeophytes. Among these the rhodophyte Palmaria decipiens, the phaeophyte Desmarestia menziesii and the chlorophyte Monostroma hariotii comprised the greatest proportions of algal biomass. A food selection study showed four algae to be preferred ( $P$. decipiens, $M$. hariotii, D. menziesii, Iridaea cordata) and two species to be avoided (Desmarestia anceps and Himantothallus grandifolius) by $N$. coriiceps. The present investigation indicates that this fish feeds not only intentionally, but also selectively, on macroalgae. Preference for particular algal species is not related to associated epifaunal biomass or to associated amphipod biomass.
\end{abstract}

Received 24 October 1996, accepted 9 June 1997

Key words: Antarctic fish, feeding ecology, food selection, macroalgae, Notothenia coriiceps

\section{Introduction}

The coastal waters along the west side of the Antarctic Peninsula and nearby islands are characterized by a rich and dense macroalgal flora composed of annual and perennial species (Skottsberg 1941, Neushul 1965, Moe \& DeLaca 1976, Richardson 1979, Zielinski 1981, Etcheverry 1983, Heywood \& Whitaker 1984, Picken 1985, Zielinski 1990, Chung et al. 1994, Klöser et al. 1994). Huge amounts of algae are degraded, until they are a suitable food resource for benthicorganisms (Richardson 1979, Zielinski 1981, Brouwer 1996). Detached algae can be decomposed by biological and hydrodynamical processes (Reichardt \& Dieckmann 1985, Rieper-Kirchner 1989, Rakusa-Suszczewski 1993) and some may drift into deeper waters to provide food for benthic deposit and suspension feeders (Fischer \& Wiencke 1992, Lawson et al. 1993). The significance of living macroalgae as food for invertebrates and demersal fish in the Antarctic marine ecosystem, however, is less well understood (Richardson 1977, Brand 1980, Iken 1996).

Notothenia coriiceps Richardson (previously referred to as $N$. neglecta (Nybelin)) is the dominant inshore demersal fish in waters of the west Antarctic Peninsula, including the South Shetland Islands, Palmer Archipelago, and the South Orkney Islands (Fisher \& Hureau 1985, Gon \& Heemstra 1990, Barrera-Oro 1996). N. coriiceps remains nearshore once it becomes demersal after an early pelagic phase (White et al. 1982, Burchett et al. 1983, Casaux et al. 1990), although observations around Elephant Island indicate that it migrates to deeper waters for spawning (Kock 1989). Like other inshore demersal fish of the Southern Ocean, $N$. coriiceps is mainly abundant in areas of high macroalgal density (Moreno \& Zamorano 1980, Zukowski 1980, Casaux et al. 1990).

Macroalgae constitute a significant part of the diet of $N$. coriiceps from the South Shetland and the South Orkney regions (Richardson 1975, Moreno \& Zamorano 1980, Linkowski et al. 1983, Barrera-Oro \& Casaux 1990, Casaux et al. 1990). From the correlated occurrence of amphipods and algae in the stomachs of $N$. coriiceps at South Bay, Doumer Island, Moreno \& Zamorano (1980) concluded that such algae were ingested accidentally while preying on invertebrates. Recent investigations in Potter Cove, however, revealed that algae were a major food item of $N$. coriiceps (Barrera-Oro \& Casaux 1990) and that there was no correlation between amphipod and algal occurrence (Casaux et al. 1990). These results suggest deliberate grazing on macroalgae.

In this study we investigate

i) whether $N$. coriiceps selects actively from among the algal species available, and

ii) whether preference for algal species is related to the biomass of associated fauna.

\section{Material and methods}

Sampling was carried out in Potter Cove, King George Island, South Shetland Islands, near the Jubany Station \& Dallmann Laboratory $\left(62^{\circ} 14^{\prime} \mathrm{S}, 58^{\circ} 40^{\prime} \mathrm{E}\right)$ (Fig.1). Potter Cove is a small $\left(6 \mathrm{~km}^{2}\right)$ side bay of Maxwell Bay. The outer shores consist of rocky bottom covered by a dense algal community extending from the intertidal to about $40 \mathrm{~m}$ depth (Klöseret al. 1993). Sampling for fish and algae were carried 
out at the northern coast of the outer Potter Cove (Fig.1).

A total of 176 Notothenia coriiceps specimens were collected from November 1993-February 1994 by means of trammel nets. Fishing depth varied between 7 and $35 \mathrm{~m}$. Total length and weight of all specimens were determined and stomachs were preserved in $96 \%$ ethanol for later identification of their content.

The stomach contents of each specimen were separated into the macroalgal and the animal fractions and weighed (g Wet Weight). Algal species were determined by light microscopy of cross-sections (Lamb \& Zimmermann 1977). Frequency of occurrence and mean biomass ( $\mathrm{g} \mathrm{WW}$ ) of all algal species were determined.

The species composition of the macroalgal community was determined by repeated transect sampling. Four transects were sampled from December 1993-February 1994 (Fig.1). Along each transect, three replicates of $0.25 \mathrm{~m}^{2}$ were sampled by SCUBA diving at four depths $(5,10,15,25 \mathrm{~m})$. Average biomass of each algal species was computed by pooling the data of all transects for the particular species in order to minimize sampling errors due to patchy distribution. The chlorophyte Monostroma hariotii is very abundant above $5 \mathrm{~m}$ water depth, but did not occur within the depth range sampled. Based on quantitative data derived from Iken (unpublished data) and Klöser et al. (1996), the share of $M$. hariotii in total macroalgal biomass was estimated to be $2 \%$.

To determine the amount of epifauna per algal species, one or more (depending on size) specimens of the most common 11 algal species and their associated epifauna were sampled with nets (mesh size $<0.2 \mathrm{~mm}$ ) by SCUBA diving. The epifauna was sorted into major taxa and the algae and fauna were weighed ( $\mathrm{g} \mathrm{WW}$ ).

To compare the availability of macroalgae in the benthos and their usage by $N$. coriiceps, we applied the "Linear Food Selection Index L" (Strauss 1979). The Linear Food Selection Index $L_{i, j}$ was calculated for each alga $\mathrm{i}(\mathrm{i}=1, \ldots, N ; N=20$, see results) and each fish j ( $\mathrm{j}=1, \ldots, M ; M=148)$ :

$$
\mathrm{L}_{\mathrm{i}, \mathrm{j}}=\mathrm{RBF}-\mathrm{RBB} \quad\left[\mathrm{RBF}=100 \cdot \mathrm{B}_{\mathrm{j}} / \Sigma \mathrm{B}_{\mathrm{j}} ; \mathrm{RBB}=100 \cdot \mathrm{B}_{\mathrm{i}} / \mathbf{\Sigma} \mathrm{B}_{\mathrm{i}}\right]
$$

where $\Sigma B_{j}$ is the total algal biomass in fish $j$ and $\Sigma B_{j}$ the total benthic algal biomass. This index is the difference between the relative biomass of the alga species $i$ in the stomach of fish $j$ (RBF) and the relative biomass of the same alga species $i$ in the benthos (RBB). Positive or negative values of $L_{i, j}$ indicate preference or rejection of alga species $\mathrm{i}$ by the fish $\mathrm{j}$, respectively.

RBF was derived from stomach content analysis. Only those stomachs $(N=148)$ which contained macroalgal species occurring also in the benthos samples were included in the selection study. Thus, overestimation of preference for those algae which were extremely rare or unrepresented in the transects due to the sampling profile (see above) was avoided. RBB was computed from the transect data.

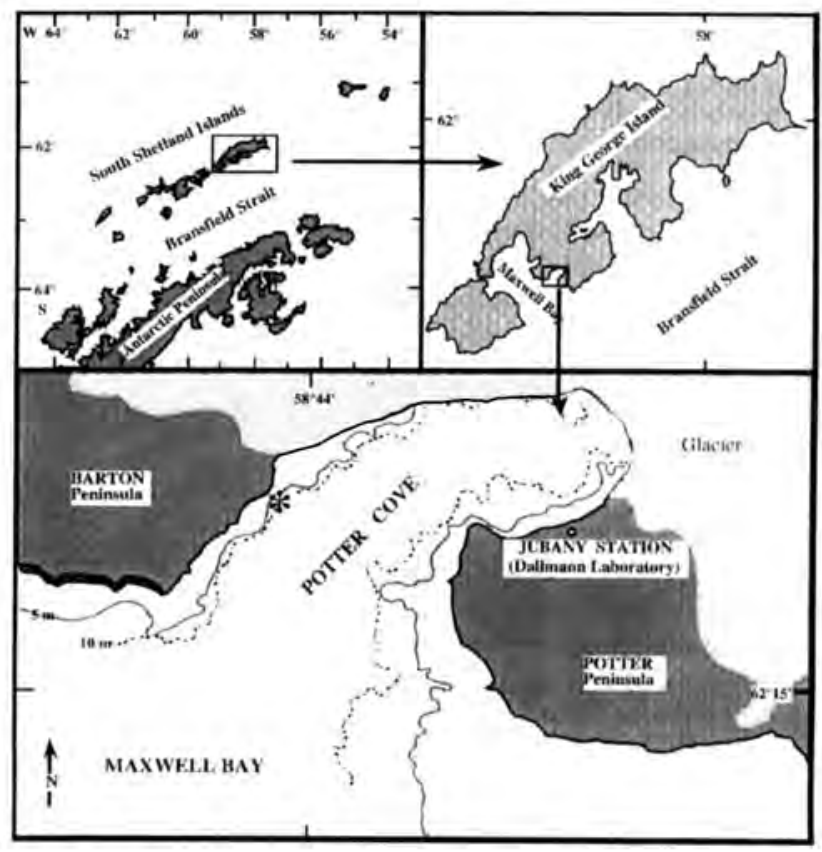

Fig. 1. General view of King George Island, South Shetland Islands and the location of Potter Cove. Sampling area is marked with an asterisk $\left({ }^{*}\right)$.

Prefe renceof $N$. coriiceps for algal species was statistically tested by analysis of variance (ANOVA) of the Box-Cox transformed (Sokal \& Rohlf 1992) $\mathrm{L}_{\mathrm{i}, \mathrm{j}}$ data and subsequent Post-Hoc-Test on differences among means. Some of the algal species occurring in the benthos were not found in the stomach contents at all, i.e. index values of these algae were always zero and hence lacking variances which made statistical comparison impossible. To overcome this problem, we added random statistical noise (normal distribution with mean $=0$ and standard deviation $=2 \cdot 10^{-4}$ ) to all $\mathrm{L}_{\mathrm{i}, \mathrm{j}}$ data prior to ANOVA.

To check for relations between preference for algal species and the associated epifauna, we grouped the 11 sampled algal species (see above) according to the results of the selection analysis into two groups (preferred, not preferred). The biomass of total epifauna and the biomass of amphipods (both log-transformed) as well as the percentage of amphipods (arcsin-transformed), which were assumed to be the main prey of N. coriiceps (Barrera-Oro \& Casaux 1990, Casaux et al. 1990), were then compared by the Mann-Whitney test.

\section{Results}

From a total of 176 stomachs analysed, $97 \%$ contained food; only five stomachs were completely empty. Twenty five stomachs contained animal items only, and 10 stomachs only algal material. The mean proportion of animal components was $61.5 \%$ by weight, the mean proportion of algae was $38.5 \%$. Frequency of occurrence of macroalgae in the stomachs was $85.8 \%$. 
Table I. Algal species investigated and their frequency of occurrence in the fish stomachs, and their relative biomass (\%) in the stomachs (RBF) and in the benthos (RBB). (a) and (b) express preference and rejection by $N$. coriiceps, respectively; (1) species is rarely occuring below $5 \mathrm{~m}$ depth, (2) species is not occurring below $5 \mathrm{~m}$ depth.

\begin{tabular}{|c|c|c|c|c|}
\hline Macroalgal species & & frequency & RBF & RBB \\
\hline Monostroma hariotii Gain (a) & (Chloroph.) & 31.82 & $21.8 \pm 34.0$ & $2.0(1)$ \\
\hline Urospora penicilliformis (Roth) Areschoug & (Chloroph.) & 0.57 & $<0.1 \pm<0.1$ & 0 (2) \\
\hline Desmarestia menziesii J. Agardh. (a) & (Phaeoph.) & 61.93 & $22.4 \pm 34.3$ & 8.7 \\
\hline Desmarestia antarctica Moe et Silva & (Phaeoph.) & 10.80 & $4.7 \pm 18.3$ & 5.7 \\
\hline Desmarestia anceps Montagne (b) & (Phaeoph.) & 3.98 & $1.1 \pm 8.8$ & 50.4 \\
\hline Adenocystis utricularis (Bory) Skottsberg & (Phaeoph.) & 6.25 & $0.2 \pm 1.6$ & $0 \quad(1)$ \\
\hline Ascoseira mirabilis Skottsberg & (Phaeoph.) & 1.71 & $0.1 \pm 0.8$ & 0.3 \\
\hline Phaeurus antarcticus Skottsberg & (Phaeoph.) & 3.34 & $0.1 \pm 0.6$ & $<0.1$ \\
\hline Himantothallus grandifolius (A. et E.S. Gepp) Zinova (b) & (Phaeoph.) & 0 & 0 & 27.8 \\
\hline Palmaria decipiens (Reinsch.) R.W. Ricker (a) & (Rhodoph.) & 60.23 & $28.3 \pm 35.2$ & 1.3 \\
\hline Iridaea cordata (Turner) Bory de Saint Vincent (a) & (Rhodoph.) & 27.84 & $6.3 \pm 18.0$ & 0.2 \\
\hline Gigartina skottsbergii Setchell et Gardner & (Rhodoph.) & 2.27 & $0.1 \pm 0.9$ & 1.5 \\
\hline Neuroglossum ligulatum(Reinsch)Kylin & (Rhodoph.) & 8.52 & $2.6 \pm 12.2$ & $<0.1$ \\
\hline Plocamium cartilagineum (Linn.) Dixon & (Rhodoph.) & 6.25 & $1.2 \pm 7.0$ & 2.7 \\
\hline Georgiella confluens (Reinsch) Skottsberg & (Rhodoph.) & 1.14 & $0.2 \pm 2.6$ & 0.7 \\
\hline Curdiea racovitzae Hariot in De Wildeman & (Rhodoph.) & 0.57 & $<0.1 \pm 0.2$ & 0.1 \\
\hline Gymnogongrus antarcticus Skottsberg & (Rhodoph.) & 0.57 & $<0.1 \pm<0.1$ & $<0.1$ \\
\hline Pantoneura plocamioides Kylin & (Rhodoph.) & 0.57 & $<0.1 \pm 0.1$ & 0 \\
\hline Porphyra endivifolium (Gepp et Gepp) Chamberlain & (Rhodoph.) & 3.98 & $0.5 \pm 2.8$ & $0(2)$ \\
\hline Kallymenia antarctica Hatiot & (Rhodoph.) & 0 & 0 & 0.4 \\
\hline Ballia callitricha(Agardh) Kützing & (Rhodoph) & 0 & 0 & 0.1 \\
\hline Myriogramme smithii (Hooker fil. et Harvey) Kylin & (Rhodoph.) & 0 & 0 & $<0.1$ \\
\hline Hymenocladiopsis crustigena Moe & (Rhodoph.) & 0 & 0 & 0.1 \\
\hline Phyllophora ahnfeltioides Skottsberg & (Rhodoph.) & 0 & 0 & $<0.1$ \\
\hline Sarcodia montagneana (Hooker fil. et Harvey) Agardh & (Rhodoph.) & 0 & 0 & $<0.1$ \\
\hline undetermined plant substance & & 25.57 & $10.4 \pm 24.2$ & \\
\hline
\end{tabular}

Krill (Euphausia superba Dana) was the most important animal prey (c. $80 \%$ by weight), followed by amphipods, gastropods and isopods. The algal diet consisted of 18 species - 2 Chlorophyta, 10 Rhodophyta, 6 Phaeophyta (Table I), with Palmaria decipiens, Monostroma hariotii, and Desmarestia menziesii comprising the greatest portion of algal biomass.

Fish length varied between $16-45 \mathrm{~cm}$, and fish weight between $48-1288 \mathrm{~g} \mathrm{WW}$; no significant correlation was found between fish size and the amount of algae in the stomach.

Benthic transect samples of algae consisted of 21 species, 1 chlorophyte, 6 phaeophytes, and 14 rhodophytes. The mean relative biomass of each algal species found in the transects and in the fish stomachs is shown in Table I. Among the algal species ingested, $P$. decipiens, $M$. hariotii, D. menziesii, andIridaea cordata were significantly preferred $(P<0.001)$, whereas Himantothallus grandifolius and Desmarestia anceps were significantly avoided $(P<0.001)$. For the remaining 15 species, neither significant preference nor rejection was detected, i.e. $N$. coriiceps is indifferent with respect to those species (Fig. 2).

Algal species, their total associated epifaunal biomass, the biomass of associated amphipods, and the percentage of amphipods in the epifauna, are listed in Table II. The MannWhitney test could not detect any relationship between the two algal catagories (preferred, not preferred) and total biomass of epifauna $(P=0.8774)$, amphipod biomass $(P=0.5371)$, or the percentage of amphipods in the epifauna $(P=0.6434)$.

\section{Discussion}

Feeding on macroalgae is common among fishes, mainly in tropical marine ecosystems (Horn 1989). In the Antarctic, grazing has been observed in a number of Nototheniids (Richardson 1975, Moreno \& Zamorano 1980, Burchett 1983, Burchett et al. 1983, Linkowski et al. 1983, BarreraOro \& Casaux 1990, Casaux et al. 1990, Coggan 1993, Gröhsler 1994). Among Antarctic studies, however, there is still a debate whether fish intentionally consume macroalgae (Daniels 1982, Barrera-Oro \& Casaux 1990, Casaux et al. 1990 ) or accidentally ingest plant material while predating epifauna associated with macroalgae (Moreno \& Zamorano 1980). With respect to Notothenia coriiceps, our results confirm the conclusion of Barrera-Oro \& Casaux (1990) and Casaux et al. (1990) that this species deliberately ingests macroalgae. We found macroalgae to occur with high frequency (c. 86\%) in the stomachs of $N$. coriiceps, as also reported by Barrera-Oro \& Casaux (1990) (80\%, Potter Cove) and by Moreno \& Zamorano (1980) (88\%, South Bay, Doumer Island), but more frequently than around Signy Island (40\%, Richardson 1975, c. 5\% in juveniles, Coggan 1993). The mean algal proportion of the stomach content 


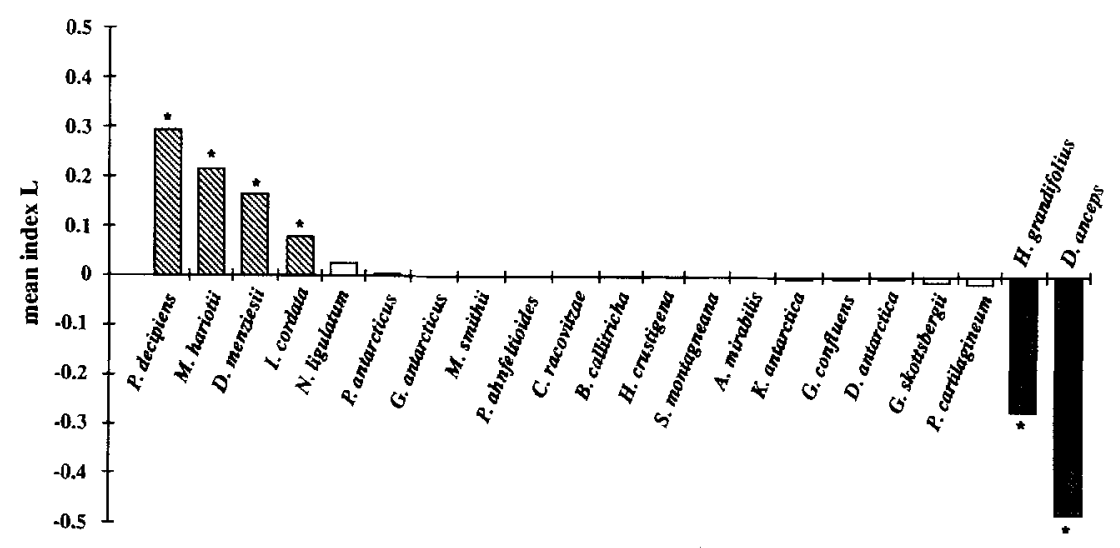

Fig. 2. Linear Food Selection Index $L$ of algal species ingested by $N$. coriiceps. Significant differences $(P<0.001)$ are marked (*). was high ( $38.5 \%$ by weight) compared with the results of Casaux et al. 1990 (c. 5\%).

Our identification of 18 algal species in the diet of $N$. coriiceps greatly exceeds the numbers recorded in previous investigations, which either did not distinguish between species at all (Richardson 1975, Barrera-Oro \& Casaux 1990, Coggan 1993) or identified a few species only (Moreno \& Zamorano 1980). It is likely that, due to the lack of hard structures, macroalgae are often not recognized and therefore underestimated in stomach content analyses. Algal species with the highest portion of biomass in the stomach contents were the red alga Palmariadecipiens, the brown alga Desmarestiamenziesii, and the green alga Monostroma hariotii (Table I). The red and the green algal species have not been recorded previously as food items of $N$. coriiceps.

None of the previous studies of $N$. coriiceps analysed feeding selectivity with respect to macroalgae in detail. Barrera-Oro \& Casaux (1990) found macroalgae to be one of seven preferred food items of $N$. coriiceps in Potter Cove, while for juvenile fish at Signy Island algae were classified as tertiary (summer) or incidental (other seasons) prey only (Coggan 1993). Our study, however, shows a distinct selection of certain algal species from those available: Four species, Palmaria decipiens, Monostroma hariotii, Desmarestia menziesii, Iridaea cordata, were significantly preferred and two species, Desmarestia anceps, Himantothallus grandifolius, were significantly avoided (Fig.2). The latter are abundant key species of the algal community below $10 \mathrm{~m}$ depth in Potter Cove (Klöser et al. 1996). Obviously, the selection strategy of $N$. coriiceps is independent of the availability (in terms of abundance or biomass) of algal species.

Further investigations are required to evaluate the overall significance of distinct macroalgal species to the diet of $N$. coriiceps, since little is known about their calorific values, and the energy intake in general is presumably low while feeding on algae (Coggan 1993). Chlorophytes and Rhodophytes are considered easily digestible, while brown algal constituents are mainly assimilable after microbial fermentation only (Montgomery \& Gerking 1980).
Our comparison of the amount of epifauna associated with the two algal groups identified (preferred, not preferred) shows clearly that the preference for certain algal species is not related to total epifauna or to epifaunal amphipods (Table II). On the contrary, some algae with few epifauna, such as $P$. decipiens, are preferred whereas $N$. coriiceps is indifferent to some algae which harbour a rich epifauna. The contradictory findings of Moreno \& Zamorano (1980) may have resulted from their limited approach, i.e. analysis of the stomach contents without a concurrent study of the epifaunal communities associated with distinct macroalgal species.

It should be noted, however, that sampling of algal epifauna was carried out by day and that the proportions of epifauna with nocturnal activity might be slightly different by night. Feeding activity of $N$. coriiceps is supposed to be higher in darkness (Richardson 1975, Moreno \& Zamorano 1980),

Table II. Algal species and the total biomass of associated epifauna as well as the biomass and percentage of amphipods. Weights in $\mathrm{g}$ WW. Preference for algal species by $N$. coriiceps is characterized as + (preferred) and - (not preferred).

\begin{tabular}{llrrrr}
\hline $\begin{array}{l}\text { sample algal species } \\
\text { no }\end{array}$ & \multicolumn{1}{c}{$\begin{array}{c}\text { total epifauna } \\
\left(\mathrm{g} 100 \mathrm{~g}^{-1} \text { algae }\right)\left(\mathrm{g} 100 \mathrm{~g}^{-1} \text { algae }\right)\end{array}$} \\
\hline & \multicolumn{1}{c}{ amphipods } & \multicolumn{2}{c}{ amphipods preference } \\
1 & M. hariotii & 0.5838 & 0.0118 & 1.34 & + \\
2 & M. hariotii & 4.7576 & 2.7113 & 56.98 & + \\
3 & I. cordata & 12.1079 & 4.0230 & 33.23 & + \\
4 & I. cordata & 3.9794 & 3.1467 & 79.08 & + \\
5 & I. cordata & 6.4809 & 0.1724 & 2.66 & + \\
6 & P. decipiens & 0.0671 & 0.0000 & 0.00 & + \\
7 & D. menziesii & 15.0633 & 3.8964 & 25.87 & + \\
8 & D. menziesii & 9.1922 & 5.1376 & 55.89 & + \\
9 & G. skottsbergii & 3.8277 & 0.8195 & 21.41 & - \\
10 & G. confluens & 95.9185 & 3.3143 & 3.46 & - \\
11 & G. confluens & 24.1214 & 3.5769 & 14.83 & - \\
12 & P. cartilagineum & 14.9182 & 9.0034 & 60.35 & - \\
13 & $P$. cartilagineum & 28.4211 & 2.4385 & 8.58 & - \\
14 & P. antarcticus & 1.0569 & 0.4053 & 38.35 & - \\
15 & A. mirabilis & 9.7294 & 0.0973 & 1.00 & - \\
16 & A. mirabilis & 3.4226 & 0.1328 & 3.88 & - \\
17 & D. anceps & 1.2386 & 0.6177 & 49.87 & - \\
18 & H. grandifolius & 0.0322 & 0.0307 & 95.27 & - \\
19 & H. grandifolius & 0.0757 & 0.0269 & 35.46 & - \\
20 & H. grandifolius & 0.0344 & 0.0283 & 82.13 & - \\
\hline
\end{tabular}


although recent investigations of Casauxet al. (1990) showed an activity peak of the fish during daytime.

While stomach content analyses provide information about the relative importance of single food items and about feeding strategies (e.g. generalist or specialist), food selection studies deliver a more detailed picture of feeding habits and strategies. Hence, they may contribute to the understanding of trophic interactions between algae and grazers and their impact on the structure of algal communities. Klöser et al. (1994) suggested that selective grazing of $N$. coriiceps on Desmarestia anceps may cause the replacement of this alga by Himantothallus grandifolius in the deep sublittoral algal community of Potter Cove. Although stomach content analyses showed $D$. anceps to be part of the diet of $N$. coriiceps, the food preference study showed this alga to be significantly rejected compared to its availability in the benthos (Fig. 2). Hence, grazingof $N$. coriiceps on $D$. anceps is unlikely to affect the competition between $D$. anceps and $H$. grandifolius significantly. However, grazing of $N$. coriiceps on Desmarestia menziesii and its avoidance of $D$. anceps may play a role in the spatial competition of these two algal species (Klöser et al. 1996).

Our results indicate that living macroalgae may be a more important food source for the Antarctic shallow water benthic fauna than previously assumed. The extended usage of macroalgae by shallow water demersal fish indicates strong food limitation and a tendency towards wider trophic niches to minimize food competition.

\section{Acknowledgements}

We gratefully acknowledge the help of all our scientific and non-scientific colleagues on the Antarctic base "Jubany". The first author especially thanks Prof Dr W. Arntz (Alfred Wegener Institute) for his support and his valuable comments on prior versions of the manuscript. We would also like to thank $\mathrm{O}$. Gon, J. Macdonald and $\mathrm{M}$. White who reviewed the paper. The second author was financially supported by the Deutscher Akademischer Austauschdienst (DAAD) during his stay at AWI. This is AWI Publication No. 1151.

\section{References}

BARRERA-ORO, E.R. 1996. Ecology of inshore demersal Antarctic fish (Notothenioidei) from the South Shetland Islands. Ph.D thesis, University of Bremen, $67 \mathrm{pp}$. [Unpublished.]

Barrera-Oro, E.R. \& CasauX, R.J. 1990. Feeding selectivity in Notothenia neglecta, Nybelin, from Potter Cove, South Shetland Islands, Antarctica, Antarctic Science, 2, 207-213.

BRAND, T.E. 1980. Trophic interactions and community ecology of the shallow-water marine benthos along the Antarctic Peninsula. Ph.D thesis, University of California, $220 \mathrm{pp}$. [Unpublished.]

BroUwER, P.E.M. 1996. Decompositionin situ of the sublittoral Antarctic macroalga Desmarestia anceps Montagne. Polar Biology, 16, 129-137.
BurCHETT, M.S. 1983. Food, feeding and behaviour of Notothenia rossii nearshore at South Georgia. British Antarctic Survey Bulletin, No. 61, 45-51.

Burchett, M.S.,S Ayers, P.J., NorTh, A.W. \&White, M.G. 1983. Some biological aspects of the nearshore fish populations at South Georgia. British Antarctic Survey Bulletin, No. 59, 63-74.

CasauX, R.J., MazzotTa, A.S. \& Barrera-Oro, E.R. 1990. Seasonal aspects of the biology and diet of nearshore nototheniid fish at Potter Cove, South Shetland Islands, Antarctica. Polar Biology, 11, 63-72.

Chung, H., Оh, Y.S.,LeE, I.K. \& Kim, D.Y. 1994. Macroalgal vegetation of Maxwell Bay in King George Island, Antarctica. Korean Journal of Phycology, 9, 47-58.

CogGan, R.A. 1993. Trophodynamics of the Antarctic fish Notothenia coriiceps Richardson. Ph.D thesis, Open University, 182 pp. [Unpublished.]

Danlels, R.A. 1982. Feeding ecology of some fishes of the Antarctic Peninsula. Fishery Bulletin, 80, 575-588.

EtCheverry, H. 1983. Algas bentónicas de la Antártica Chilena. Serie Cientifica INACH, 30, 97-124.

FISCHER, W. \& HUREAU, J.C., eds. 1985. FAO species identification sheets for fishery purposes, Southern Ocean, Vol. II. Rome: Food and Agriculture Organization, 233-471.

FisCHER, G. \& WiENCKe, C. 1992. Stable carbon isotope composition, depth distribution and fate of macroalgae from the Antarctic Peninsula region. Polar Biology, 12, 341-348.

Gon, O. \& HeEmstra, P.C., eds. 1990. Fishes of the Southern Ocean. Grahamstown: J.L.B. Smith Institute of Ichthy ology, 462 pp.

GROHSLER, T. 1994. Feeding habits as indicators of ecological niches: Investigations of Antarctic fish conducted near Elephant Island in late autumn/winter 1986. Archive of Fishery and Marine Research, 42, $17-34$.

HeYwood, R.B. \&Whitaker, T.M. 1984. The Antarctic flora. In Laws, R.M., ed. Antarctic ecology, Vol.2. London: Academic Press,373.419.

HORN, M.H. 1989. Biology of marine herbivorous fishes. Oceanography and Marine Biology Annual Review, 27, 167-272.

IKEN, K. 1996. Trophic relations between macroalgae and herbivores in Potter Cove (King George Island, Antarctica). Berichte zur Polarforschung, 201, 1-206. [in German]

Kloser, H., Ferreyra, G., Schloss, I., Mercur1, G., Laturnus, F. \& Curtosi, A. 1993. Seasonal variation of algal growth conditions in sheltered Antarctic bays: the example of Potter Cove (King George Island, South Shetlands). Journal of Marine Systems, 4, 289-301.

Kloser, H., Mer cur1, G., Laturnus, F., Quartino, M.L. \& Wiencke, C. 1994. On the competitive balance of macroalgae at Potter Cove (King George Island, South Shetlands). Polar Biology, 14, 11-16.

Kloser, H., Quartino, M.L. \& Wiencke, C. 1996. Distribution of macroalgae and macroalgal communities in gradients of physical conditions in Potter Cove, King George Island, Antarctica. Hydrobiologia, 333, 1-17.

Kock, K.H. 1989. Reproduction in fish around Elephant Island. Archiv für Fischereiwissenschaft, 39, 171-210.

LAMB, I.M. \& ZimmermanN, M.H. 1977. Benthic marine algae of the Antarctic Peninsula. Antarctic Research Series, 23, 130-229.

LAwson, G.S., Tyler, P.A. \& Youno, C.M. 1993. Attraction of deep-sea amphipods to macrophy te food falls. Journal of Experimental Marine Biology and Ecology, 169, 33-39.

Linkowski, T.B., Presler, P. \& Zukowski, C. 1983. Food habits of nototheniid fishes (Nototheniidae) in Admiralty Bay (King George Island, South Shetland Islands). Polish Polar Research, 4, 79-95.

MOE, R.L. \&DELACA, T.E. 1976. Occurrence of macroscopic algae along the Antarctic Peninsula. Antarctic Journal of the United States, 11, 20-24.

Montgomery, W.L. \& Gerking, S.D. 1980. Marine macroalgae as food for fishes: An evaluation of potential food quality. Environmental Biology and Fisheries, 5, 143-153. 
Moreno, C.A. \& Zamorano, J.M. 1980. Séleccion de los alimentos en Notothenia coriiceps neglecta del cinturon de macroalgas de Bahía South Antarctica. Serie Cientifica INACH, 25-26, 33-43.

Neushul, M. 1965. Diving observations of sub-tidal Antarctic marine vegetation. Botanica Marina, 8, 235-243.

PICKEN, G.B. 1985. Marine habitats - Benthos. In Bonner, W.N. \& Walton, D.W.H., eds. Key environments - Antarctica. Oxford: Pergamon Press, 154-172.

RakUSa-Suszczewski, S. 1993. Matter transport and budgets in the Admiralty Bay area. In RakusA-SuszczEwsKI, S., ed. The Maritime Antarctic coastal ecosystem of Admiralty Bay. Warsaw: Polish Academy of Sciences, 199-212.

ReICHARDT, W. \& DieckManN, G. 1985. Kinetics and trophic role of bacterial degradation of macro-algae in Antarctic coastal waters. In Siegrried, W.R., Condy, P.R. \& LAws, R.M., eds, Antarctic nutrient cycles and food webs. Berlin: Springer-Verlag, 115-122.

RICHARDSON, M.G. 1975. The dietary composition of some Antarctic fish. British Antarctic Survey Bulletin, Nos 41 \& 42, 113-120.

RICHARDSON, M.G. 1977. The ecology (including physiological aspects) of selected Antarctic marine invertebrates associated with inshore macrophytes. Ph.D. thesis, University of Durham, 296 pp. [Unpublished.]

RICHARDSON, M.G. 1979. The distribution of Antarctic marine macroalgae related to depth and substrate. British Antarctic Survey Bulletin, No. 49, 1-13.
RiEPER-KIRCHNER, M. 1989. Microbial degradation of North Sea macroalgae: field and laboratory studies. Botanica Marina, 32, 241-252.

Skotrsazro, C. 1941. Communities of marine algae in Subantarctic and Antarctic waters. Kunlinga Syenska Vetenskapsakademiens Handlingar / Tredje Serien, 19(4), 1-95.

Sokal, R.R. \& RohLF, F.J. 1992. Biometry, 2ndedition. San Francisco: W.H. Freeman, 207 pp.

Strauss, R.E. 1979. Reliability estimates for Ivlev's Electivity Index, the Forage Ratio, and a proposed Linear Index of Food Selection. Transactions of the American Fisheries Society, 108, 344-352.

White, M.G., North, A.W., Twelves, E.L. \& Jones, S. 1982. Early development of Notothenia neglecta from the Scotia Sea, Antarctica. Cybium, 6, 43-51.

ZlELINSK, K. 1981. Benthic macroalgae of Admiralty Bay (King George Island, South Shetland Islands) and circulation of algal matter between the water and the shore. Polish Polar Research, 2, 71-94.

Z1ELINSXI, K. 1990. Bottom macroalgae of the Admiralty Bay (King George Island, South Shetlands, Antarctica). Polish Polar Research, 11, 95-131.

Zuxowskı, C. 1980. Catches of fishes of the genus Notothenia and Trematomus at Admiralty Bay (King George Island, South Shetland Islands) in the winter-spring season, 1977. Polish Polar Research, 1, 163-167. 